Lung cancer is the second most common malignancy in the Western world and the most common cause of cancer-related death. Recent innovations in diagnosis, staging, and management of early stage and locally advanced non-small cell lung cancer have changed the paradigm for surgical management of lung cancer patients. A virtual explosion of technological development has enabled widespread use of minimally invasive approaches that current and future thoracic surgeons must embrace to improve the care of patients with lung cancer. The AATS has chosen to highlight these recent developments in its inaugural "Focus on Thoracic Surgery." The faculty for this program is internationally recognized experts in lung cancer and application of new technology for its surgical management.

\section{Educational Objectives}

- Analyze the current role of endoscopic strategies for lung cancer diagnosis and staging
- Learn the advantages and limitations of limited resection for early stage lung cancer

- Appreciate the role of surgical resection in patients with locally advanced and nodal metastatic disease

- Identify the various approaches to minimally invasive pulmonary resection

- Understand the technical challenges and results of extended pulmonary resection

- Learn the current role of stereotactic body radiotherapy (SBRT) in the management of early stage non-small cell lung cancer

The American Association for Thoracic Surgery is accredited by the Accreditation Council for Continuing Medical Education to provide continuing medical education for physicians. This live activity has been approved for $\boldsymbol{A M A}$ PRA Category 1 Credits ${ }^{\mathrm{TM}}$.

\title{
The Western Thoracic Surgical Association
}

\section{WTSA 38th Annual Meeting}

June 27-30, 2012

The Grand Wailea Hotel

Maui, Hawaii

Visit the WTSA Web site at www.westernthoracic.org and:

- View the scientific and social programs;

- Register before the Friday, May 18, 2012, Early Bird deadline, and avoid a $\$ 100$ increase in most registration fees;

- Reserve your hotel room as soon as possible, as the blocks of rooms at the meeting hotels will fill early; and

- Get complete details on venue activities and local attractions.

\section{SCIENTIFIC HIGHLIGHTS}

Thursday, June 23, 2011

\section{Breakfast Session*}

A Balanced Approach to Operative Services Performance Improvement Using Lean Methods

Lynn D. Martin, Seattle, Washington

\section{Presidential Address}

Robert C. Robbins, Stanford, California

Controversies in Thoracic Surgery

Gen Thoracic Surgery Is Best Taught in an I6 Program

Pro: Michael S. Mulligan, Seattle, Washington

Con: Joseph B. Shrager, Stanford, California

Friday, June 24, 2011

\section{Breakfast Session*}

How to Set Up a Transcatheter Aortic Valve Replacement Program

Michael J. Mack, Plano, Texas

\section{Postgraduate Course}

Paging Dr. Moore, STAT

Arnold Milstein, San Francisco, California

Saturday, June 25, 2011

\section{Walton Lillehei Point/Counterpoint Session:}

Open Aortic Valve Replacement vs Transcatheter Aortic Valve Replacement in the Low-Risk Patient

Open: Lawrence H. Cohn, Boston, Massachusetts

TAVR: TBD

*Separate Registration Required

\section{SOCIAL HIGHLIGHTS:}

Each registration includes access to Wednesday's New Members/Welcome Reception, Thursday's Samson Fun Run and Luau Theme Dinner, and Saturday's Family Luncheon and President's Banquet. (Registered children, ages 4-18, have access to supervised Children's Receptions during the New Members/Welcome Reception and President's Banquet.)

You may also supplement your Annual Meeting experience with these events:

- Thursday's Kayak \& Snorkel Tour*

- Thursday's Lavender Farm \& Winery Tour* 
- Friday's Golf Tournament*

- Friday's Tennis Tournament*

*Separate Registration Required

\section{ACCREDITATION}

This activity is being planned and implemented in accordance with the Essential Areas and Policies of the Accreditation Council for Continuing Medical Education (ACCME) through the joint sponsorship of the American Association

\section{Notices}

The part I (written) examination was held on December 3. It is planned that this examination will be given at multiple sites throughout the United States using an electronic format. The closing date for registration is August 1 each year. Those wishing to be considered for examination must apply online at www.abts.org.

To be admissible for the Part II (oral) examination, a candidate must have successfully completed the Part I (written) examination.

A candidate applying for admission to the certifying examination must fulfill all the requirements of the Board in force at the time the application is received. Please address all communications to the American Board of Thoracic Surgery, 633 North St Clair Street, Suite 2320, Chicago, IL 60611 (telephone: 312-202-5900).

\section{Requirements for Maintenance of Certification}

Diplomates of the American Board of Thoracic Surgery (ABTS) who plan to participate in the Maintenance of Certification (MOC) process must hold an unrestricted medical license in the locale of their practice and privileges in a hospital accredited by the JCAHO (or other organization recognized by the ABTS). In addition, a valid ABTS certificate is an absolute requirement for entrance into the Maintenance of Certification process. If your certificate has expired, the only pathway for renewal of a certificate is to take and pass the Part I (written) and the Part II (oral) certifying examinations. The names of individuals who have not maintained their certificate will no longer be published in the American Board of Medical Specialties Directories. Diplomates' names will be published upon successful completion of the Maintenance of Certification process. for Thoracic Surgery (AATS) and the Western Thoracic Surgical Association (WTSA). The AATS is accredited by the ACCME to provide continuing medical education for physicians.

This live activity has been approved for 14.5 AMA PRA Category 1 Credit $\left(s^{\mathrm{TM}}{ }^{\mathrm{TM}}\right.$. Physicians should only claim credit commensurate with the extent of their participation in the activity.

The CME requirements are 30 Category I credits earned during each year prior to application. At least half of these CME hours need to be in the broad area of thoracic surgery. Category II credits are not allowed. Interested individuals should refer to the Booklet of Information for Maintenance of Certification for a complete description of acceptable CME credits. Diplomates will be expected to submit verification of CME earned.

Diplomates in the Maintenance of Certification process will need to provide a summary of their major cases performed during the year prior to application. The practice review should not exceed 100 cases.

Diplomates in the Maintenance of Certification process will be required to complete all sections of the SESATS self-assessment examination. It is not necessary for Diplomates to purchase SESATS individually, because it will be sent to them after their application has been approved.

Diplomates may apply for Maintenance of Certification in the year their certificate expires, or if they wish to do so, they may apply up to two years before it expires. However, the new certificate will be dated 10 years from the date of expiration of their original certificate or most recent recertification certificate. In other words, going through the Maintenance of Certification process early does not alter the 10-year validation. Diplomates certified prior to 1976 (the year that time-limited certificates were initiated) are also required to participate in $\mathrm{MOC}$ if they wish to maintain valid certificates.

The deadline for submission of application for the Maintenance of Certification is May 10 of each year. All ABTS diplomates will receive a letter from the Board outlining their individual timeline and MOC requirements. A brochure outlining the rules and requirements for Maintenance of Certification in thoracic surgery is available upon request from the American Board of Thoracic Surgery, 633 North St. Clair Street, Suite 2320, Chicago, IL 60611; telephone (312) 202-5900; fax (312) 202-5960; E-mail info@abts.org. This booklet is also published on the Web site: www.abts.org. 